\title{
Correlation Model Design between College Students of Xi'an and Mobile Electronic Commerce
}

\author{
Liu Yuling
}

\author{
Shaanxi Institute of International Trade \& Commerce, Xianyang, Shaanxi 712046, China
}

Keywords: Mobile electronic commerce; correlation model; effect; path

\begin{abstract}
This paper analyzes influence factors of college students on their intention of using mobile online shopping for the first time. UTAUT theory is applied to the study on influence factors of college students' initial usage of mobile online shopping. The paper introduces perceived risk and perceived enjoyment to UTAUT theory tentatively, constructs research model and obtains data by using questionnaire inquiry. This paper conducts empirical test on proposed research model. The results indicate that five influence factor variables have different ranking incidence on initial usage intention: effort expectation $>$ social impact>perceived enjoyment> performance expectation $>$ perceived risk. Through e-commerce, it can bring about stable and high-quality mobile shopping online demand to mobile electronic commerce enterprises.
\end{abstract}

\section{Introduction}

Mobile online shopping refers to the behavior that uses Smartphone and tablet PC, etc., devices to visit mobile internet to go shopping online [1,2,3]. On the whole, transaction scale of mobile online shopping has been staying in high-speed growth stage in recent years. However, compared with traditional online shopping, its transaction scale is still smaller. Most of college students don't have experience to use mobile online shopping practically and has lower degree of acceptance on it [4]. For mobile electronic commerce enterprises, it is extremely important to know about influence factors of initially using mobile online shopping for college students. Meanwhile, college students also have important significance on mobile electronic commerce enterprises. Although their current consumption ability is limited, when they come upon the stage, they will become the main force of using mobile online shopping [5]. If college students can form a good habit of using mobile online shopping, they will become stable client groups of mobile electronic commerce enterprises in the future. Thus, the main purpose of this paper is to study factors of impacting college students' intention of using mobile online shopping initially.

This paper regards correlation application of college students' mobile ecommerce at a university in Xi'an area as research objects. Under the modeling situation of technology acceptance model, it constructs consumption attitude intention model that relates to college students' online shopping, meanwhile makes a comparison between different students, such as college students who are familiar with internet, college students who often scan e-commerce, and college students that have different network online shopping experience. By comparing with college students' attitude towards online shopping, network consumption intention, and various factors that impact college students' online shopping, as well as using questionnaire survey to collect related data, the paper carries out empirical analysis by using SPSS for collected data.

\section{Model and Design of College Students in E-Commerce Consumption Decisions}

\subsection{Modeling and Hypothesis}

In the influence factor model of college students' online shopping, this paper, based on theoretical basis of technology acceptance model, thinks that perceived online shopping usefulness has influences on Tourist Attitude and intention. For perceived online shopping mobility, online shopping risk perception, website characteristic perception and cognition of commodity factors, it just demonstrates its influences on Tourist Attitude, but it doesn't consider influences of college 
student intention. It is mainly because influences of these four factors on college students intention aren't found. Moreover, due to limitations of the research, this paper also doesn't take influences of four factors on college student intention into consideration. According to the above-mentioned discussion, the model is proposed as shown in Figure 1:

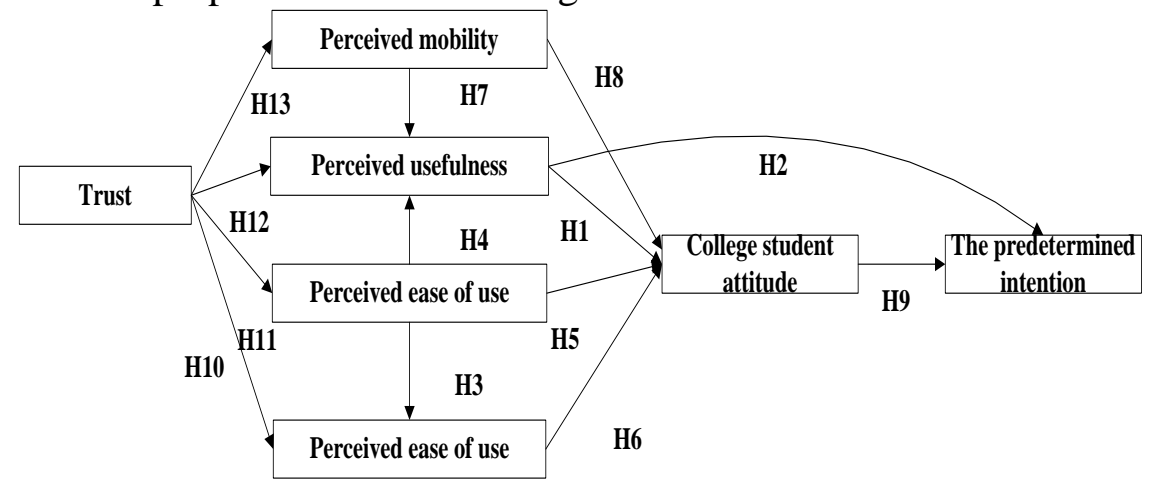

Figure 1 College Student Booking Intention Model of Mobile Electronic Commerce

This research model regards TAM model as theoretical basis and core, and combines with other multiple factors, including T, PIN, PU, EOU, PE, PM and Tourist Attitude-TA, and college student booking intention-BI, etc., eight measured variables. The model mainly includes two parts: one is toursit acceptance mobile terminal college student booking intention model, and the other one is influences of $\mathrm{T}$ and PIN on college student acceptance mobile terminal tourist booking intention model.

o verify are concluded as follows:

H1: college student indivual factors impact college student website characteristics.

H2: college student indivual factors impact college student online shopping

H3: college student indivual factors impact commodity factors

H4: college student indivual factors impact online shopping risk perception

H5: college student indivual factors impact online shopping attitude

H6: college student indivual factors impact online shopping behavior

H7: perception of college student website characteristics impacts perceived online shopping usefulness positively.

H8: perception of college student website characteristics impacts college student online shopping attitude positively.

H9: college student perceived online shopping mobility impacts perceived online shopping positively.

H10: college student perceived online shopping usefulness impacts college student online shopping attitude positively.

H11: college student perceived online shopping usefulness impacts college student online shopping intention positively.

H12: college student perceived online shopping mobility impacts college student online shopping attitude positively.

H13: college student perceived online product quality information impacts online shopping attitude positively.

\subsection{Data Analysis Tool and Method}

Data analysis adopts statistical analysis software SPSS21.0 to process research data. Through descrptive statistical analysis, it observes distribution of each data, measures degree of consistency between indicators through reliability analysis, tests significant degree of each item on variables through validity analysis, and performs a test on model hypotheses ultimately by adopting correlation analysis and regression analysis. This study adopts the most frequently-used reliability coefficient Cronbach $\mathrm{a}^{\wedge}$ iha coefficient to present the high and low degree of reliability. Criterion for reliability coefficient in this research is shown in Table 1. 
Table 1 Criterion for Realiability Coefficient

\begin{tabular}{|c|c|c|}
\hline & $\begin{array}{c}\text { Reliability coefficient of } \\
\text { questionnaire }\end{array}$ & $\begin{array}{c}\text { Univariate reliability } \\
\text { coefficient of }\end{array}$ \\
\hline $\mathrm{a}$ & 0.7 & 0.5 \\
\hline
\end{tabular}

Namely, if Cronbach $\mathrm{a}^{\wedge}$ iha coefficient of the entire scale is above 0.7 , and Cronbach $\mathrm{a}^{\wedge} \mathrm{iha}$ coefficient of each variable is above 0.5 , it indicates that reliability of this scale is good and can continue to be analyzed.

This paper adopts factor analysis method provided by SPSS21.0 to verify structure validity of the questionnaire. When factor loading of each item is more than 0.5 , structure validity can be acceptable and obvious.

\subsection{Research Objects}

This study adopts questionnaire method to collect materials and data. The questionnaire includes two parts: one is used for measuring the behavior that users use mobile internet to conduct group buying. According the measurement dimension in previous section, every question applies Likert five-point scale to measure from extreme disagreement to extreme agreement. Section two is about individual information of subjects, net years of mobile internet and time of using mobile internet every day, so as to know about using behavior of people with different backgrounds on mobile internet. In addition, the beginning of questionnaire should aim at explaining mobile internet, ensuring that subjects will have comparatively clear cognition and understanding on mobile internet.

This study adopts two ways of giving out questionnaire on the internet and providing questionnaire on the spot to conduct data collection of school students in Xi'an. Ultimately, through 221 pieces of network collections and 100 pieces of questionnaires on the spot are returned completely. There are a total of 321 pieces of questionnaires. According to a certain rule, after selecting the questionnaire and getting rid of 17 ineffective questionnaires, there are a total of 304 pieces of effective questionnaires. The effective recovery is $94.7 \%$ 。

\section{Model Empirical Analysis and Inspection}

\subsection{Correlation Analysis}

The correlation analysis between variables only indicates the tight degree and changeable direction of the relationship between two variables, but they don't explain the causal relationship between them. In order to verify performance expectation, effort expectation, social impact, perceived enjoyment, the causal relationship between perceived risk and initial usage intention provided by these research hypotheses, it is essential to conduct further regression analysis.

Table 2 performance expectation, effort expectation, social impact, perceived enjoyment, the causal relationship between perceived risk and initial usage intention. 
Table 2 performance expectation, effort expectation, social impact, perceived enjoyment, the causal relationship between perceived risk and initial usage intention.

\begin{tabular}{|c|c|c|}
\hline & & Initial usage intention \\
\hline \multirow[t]{3}{*}{ performance expectation } & \multirow[t]{3}{*}{ Pearson correlation (bilateral } & 0.511 \\
\hline & & 0 \\
\hline & & 308 \\
\hline \multirow[t]{3}{*}{ effort expectation } & \multirow{3}{*}{$\begin{array}{l}\text { Pearson correlation } \\
\text { (bilateral) }\end{array}$} & 0.479 \\
\hline & & 0 \\
\hline & & 308 \\
\hline \multirow[t]{3}{*}{ social impact } & \multirow[t]{3}{*}{ Pearson correlation (bilateral } & 0.527 \\
\hline & & 0 \\
\hline & & 308 \\
\hline \multirow[t]{3}{*}{ perceived enjoyment } & \multirow{3}{*}{$\begin{array}{l}\text { Pearson } \\
\text { (bilateral) }\end{array}$} & 0.509 \\
\hline & & 0 \\
\hline & & 308 \\
\hline \multirow[t]{3}{*}{ perceived risk } & \multirow{3}{*}{$\begin{array}{l}\text { Pearson } \\
\text { (bilateral) }\end{array}$} & -0.242 \\
\hline & & 0 \\
\hline & & 308 \\
\hline
\end{tabular}

It can be observed that degree of correlation for five variables of performance expectation, effort expectation, social impact, perceived enjoyment and perceived risk include moderate correlation and low correlation. There is no related phenomenon of high correlation. In addition, significance testing $\mathrm{P}$ value of correlation coefficient between perceived risk and performance expectation are more than 0.5 , indicating correlation and perceived hypotheses and correlation among performance expectation, effort expectation, social impact, perceived risk and initial usage intention are consistent, namely except for negative correlation of perceived risk and initial usage intention, there is positive correlation among the rest four influence factors and initial usage intention.

\subsection{Inspection of Mesomeric Effect}

Mediating variable refers to the variable that can play the function of explaining the relationship between independent variable and dependent variable. For example, $\mathrm{X}$ is independent variable, $\mathrm{Y}$ is dependent variable, $\mathrm{M}$ is mediating variable and $\mathrm{X}$ impacts $\mathrm{Y}$ in the form of influencing $\mathrm{M}$. If there is no $\mathrm{M}, \mathrm{X}$ won't impact $\mathrm{Y}$. The second one is partial mediation, namely $\mathrm{X}$ impacts $\mathrm{Y}$ by partially influencing $\mathrm{M}$, while the part of them impact $\mathrm{Y}$ directly.

This study uses a test method on inspection of mediating effect, as shown in Figure 2:

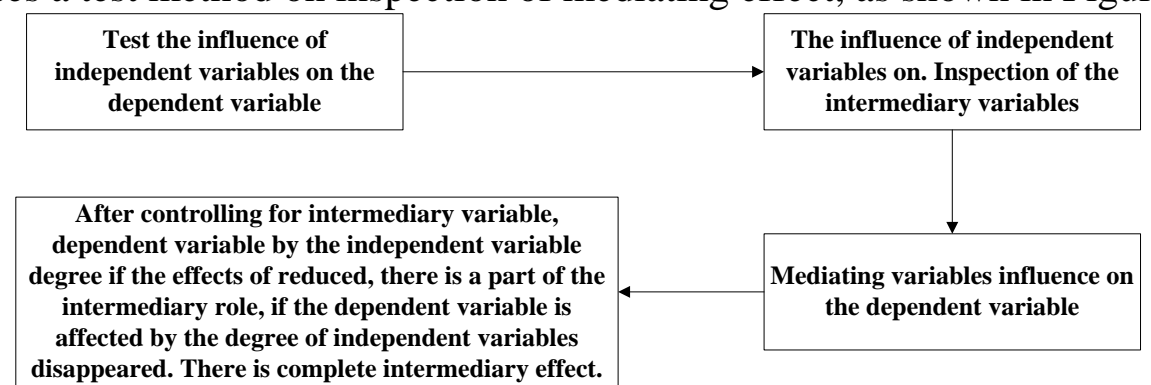

Figure 2 Checkout Procedure of Mediating Inspection

Performance expectation has mediating effect between effort expectation and initial usage intention. We conduct regression analysis on effort expectation and initial usage intention. The result is shown in Table 3: 
Table 3 Influence of Effort Expectation on Initial Usage Intention

\begin{tabular}{|c|c|c|c|c|c|c|}
\hline $\begin{array}{c}\text { Independent } \\
\text { variable }\end{array}$ & $\begin{array}{c}\text { Dependent } \\
\text { variable }\end{array}$ & $\beta$ & Standardized $\beta$ & t value & $\begin{array}{c}\text { Adjusted } \\
\mathrm{R}^{2}\end{array}$ & F value \\
\hline $\begin{array}{c}\text { Effort } \\
\text { expectation }\end{array}$ & $\begin{array}{c}\text { Initial usage } \\
\text { intention }\end{array}$ & 0.526 & 0.479 & $9.553^{* * *}$ & 0.230 & 91.529 \\
\hline \multicolumn{2}{|l|}{ Standardized regression equation: initial usage intention=0.479*effort expectation } \\
\hline
\end{tabular}

We conduct regression analysis on effort expectation and performance expectation. The result is shown in Table 3:

Table 4 Influence of Effort Expectation on Performance Expectation

\begin{tabular}{|c|c|c|c|c|c|c|}
\hline $\begin{array}{c}\text { Independent } \\
\text { variable }\end{array}$ & $\begin{array}{c}\text { Dependent } \\
\text { variable }\end{array}$ & $\beta$ & Standardized $\beta$ & t value & $\begin{array}{c}\text { Adjusted } \\
\mathrm{R}^{2}\end{array}$ & F value \\
\hline $\begin{array}{c}\text { Effort } \\
\text { expectation }\end{array}$ & $\begin{array}{c}\text { Initial usage } \\
\text { intention }\end{array}$ & 0.498 & 0.449 & $8.794 * * *$ & 0.202 & 77.326 \\
\hline \multicolumn{2}{|c|}{ Standardized regression equation: performance expectation=0.449*effort expectation } \\
\hline
\end{tabular}

We conduct regression analysis on performance and initial usage intention. The result is shown in Table 5:

Table 5 Influence of Performance on Initial Usage Intention

\begin{tabular}{|c|c|c|l|l|l|l|}
\hline $\begin{array}{c}\text { Independent } \\
\text { variable }\end{array}$ & $\begin{array}{c}\text { Dependent } \\
\text { variable }\end{array}$ & $\beta$ & Standardized $\beta$ & t value & $\begin{array}{c}\text { Adjusted } \\
\mathrm{R}^{2}\end{array}$ & F value \\
\hline $\begin{array}{c}\text { Effort } \\
\text { expectation }\end{array}$ & $\begin{array}{c}\text { Initial usage } \\
\text { intention }\end{array}$ & 0.506 & 0.511 & $10.391^{* * *}$ & 0.261 & 107.971 \\
\hline \multicolumn{2}{|c|}{ Standardized regression equation: initial usage intention=0.511* performance expectation } \\
\hline
\end{tabular}

We conduct regression analysis on effort expectation, performance expectation and initial usage intention. The result is shown in Figure 6:

Table 6 Influence of Effort Expectation and Performance Expectation on Initial Usage Intention

\begin{tabular}{|c|c|c|c|c|c|c|}
\hline $\begin{array}{l}\text { Independent } \\
\text { variable }\end{array}$ & $\begin{array}{l}\text { Dependent } \\
\text { variable }\end{array}$ & $\beta$ & Standardized $\beta$ & t value & $\begin{array}{l}\text { Adjusted } \\
\mathrm{R}^{2}\end{array}$ & F value \\
\hline $\begin{array}{c}\text { Effort } \\
\text { expectation }\end{array}$ & $\begin{array}{c}\text { Initial usage } \\
\text { intention }\end{array}$ & 0.344 & 0.313 & $6.009 * * *$ & \multirow[t]{2}{*}{0.399} & \multirow[t]{2}{*}{78.232} \\
\hline $\begin{array}{l}\text { Performance } \\
\text { expectation }\end{array}$ & $\begin{array}{c}\text { Initial usage } \\
\text { intention }\end{array}$ & 0.366 & 0.370 & $7.103 * * *$ & & \\
\hline
\end{tabular}

Through the above-mentioned four regression analyses, we can find that effort expectation plays a significant positive effect on initial usage intention. Effort expectation plays a significant positive effect on performance expectation, and performance expectation plays a significant positive effect on initial usage intention. Ultimately, through regression analysis on effort expectation, performance expectation and initial usage intention, we can found that standardized regression coefficient $\mathrm{P}$ value of effort expectation is dropped to 0.313 from 0.479 by comparing with individual standardized regression coefficient of effort expectation on initial usage intention. This proves that performance expectation plays the mediating effect between effort expectation and initial usage intention.

\subsection{Path Analysis}

Path analysis is a kind of statistical approach to analyze the relationship between variables in the modeled way. Traditionally, path analysis will consist of a series of regression analyses, combine with different equations by putting forward research hypotheses to form structured model, and conduct multiple regression with SPSS or SAS software to complete estimation of parameter model. This path analysis method is called as regression-oriented path analysis. In multiple regression analysis, there is coordinating relation between independent variables, reflecting in direct effect of independent variable on influence of dependent variable. In path analysis, it can differentiate direct 
effect and indirect effect of independent variable on influence of dependent variable. Total effect of independent variable on dependent variable is equal to the sum of direct effect and indirect effect. In the model of this paper, due to existence of mediating variable, it is necessary to differentiate direct effect and indirect effect of each influence factor on initial usage intention. Moreover, it should use total effect indicator as the criterion of contrasting influencing degree of each influence factor on initial usage intention. Influence factors' path diagram of college student initial mobile online shopping intention is shown in Figure 1.

We conduct regression analysis on initial usage intention by regarding five influence factors as independent variables, including performance expectation, effort expectation, social impact, perceived risk and perceived enjoyment, as shown in Table 7, so as to draw direct influencing effect of these five influence factors on initial usage intention. From the result of regression analysis, it can be observed that four influence factors, such as performance expectation, effort expectation, social impact and perceived enjoyment, as independent variables play a significant positive influence on initial usage intention. Perceived risk plays a significant negative influence on initial usage intention. $\mathrm{F}=52.497$, it reaches 0.001 significance level. Adjusted determination coefficient is 0.456, indicating that as independent variables, these five influence factors can explain $45.6 \%$ amount of variability for initial usage intention.

Table 7 Regression Analysis Results for Direct Impact Effect of Five Influence Factors on Initial Usage Intention:

\begin{tabular}{|c|c|c|c|c|c|}
\hline $\begin{array}{l}\text { Independent } \\
\text { variable }\end{array}$ & $\begin{array}{l}\text { Regression } \\
\text { coefficient }\end{array}$ & $\begin{array}{l}\text { Standard } \\
\text { error }\end{array}$ & $\begin{array}{l}\text { Standard } \\
\text { regression } \\
\text { coefficient }\end{array}$ & t value & $\mathrm{P}$ value \\
\hline Constant term & 0.895 & 0.332 & & 2.699 & 0.007 \\
\hline $\begin{array}{c}\text { Performance } \\
\text { expectation }\end{array}$ & 0.224 & 0.052 & 0.226 & 4.338 & 0 \\
\hline Effort expectation & 0.179 & 0.057 & 0.163 & 3.160 & 0.002 \\
\hline Social impact & 0.246 & 0.056 & 0.226 & 4,377 & 0 \\
\hline $\begin{array}{l}\text { Perceived } \\
\text { enjoyment }\end{array}$ & 0.254 & 0.052 & 0.242 & 4.923 & 0 \\
\hline Perceived risk & -0.153 & 0.057 & -0.120 & -2.686 & 0.008 \\
\hline
\end{tabular}

It can be observed that social impact and effort expectation play a significant positive effect on performance expectation. $\mathrm{F}=62.464$, it reaches 0.001 significant level. Adjusted determination coefficient is 0.286 , indicating that regarding social impact and effort expectation as variables can explain $28.6 \%$ amount of variability for performance expectation.

Through the parameter estimation results of path analysis on path coefficient, it can obtain path analysis results of influence factors on college student initial usage intention of mobile online shopping (the figure in the upper arrow of three endogenous variables, including performance expectation, perceived enjoyment and initial usage intention, is residual coefficient). 


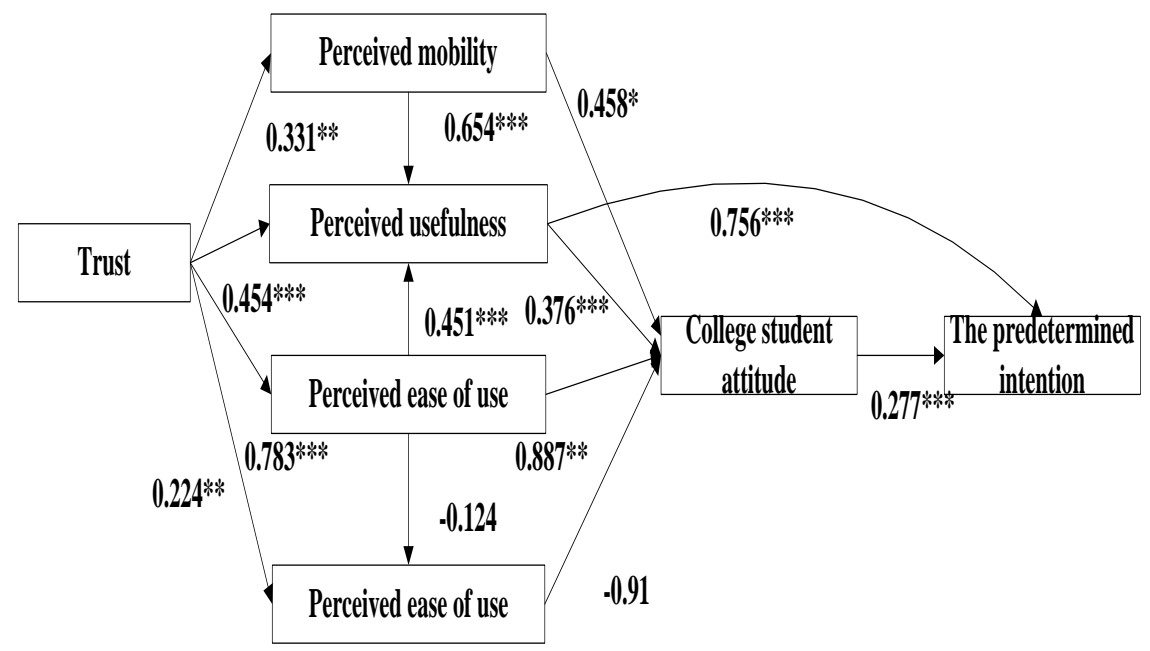

Figure 3 Path Analysis Results of Influence Factors on College Student Initial Usage Intention of Mobile Online Shopping

Indirect effect value of social impact on initial usage intention (social impact-->performance expectation-->initial usage intention) $=0.331 * 0.226=0.075$

Indirect effect value of effort expectation on initial usage intention(effort expectation--> performance expectation-->initial usage intention; effort expectation-->perceived enjoyment-->initial usage intention) $=0.305 * 0.226+0.329 * 0.242=0.149$ 。

It can be observed from the above table, important degree of each influence factor on initial usage intention: effort expectation>social impact>perceived enjoyment>performance expectation>perceived risk.

\subsection{Inspection Results}

Empirical inspection results for research hypotheses are shown in Table 8:

\begin{tabular}{|l|l|l|}
\hline Codes & Hypotheses & $\begin{array}{l}\text { Empirical } \\
\text { Results }\end{array}$ \\
\hline H1 & $\begin{array}{l}\text { college student indivual factors impact college } \\
\text { student website characteristics. }\end{array}$ & Yes \\
\hline H2 & $\begin{array}{l}\text { college student indivual factors impact college } \\
\text { student online shopping }\end{array}$ & Yes \\
\hline H3 & $\begin{array}{l}\text { college student indivual factors impact } \\
\text { commodity factors }\end{array}$ & No \\
\hline H4 & $\begin{array}{l}\text { college student indivual factors impact online } \\
\text { shopping risk perception }\end{array}$ & Yes \\
\hline H5 & $\begin{array}{l}\text { college student indivual factors impact online } \\
\text { shopping attitude }\end{array}$ & Yes \\
\hline H6 & $\begin{array}{l}\text { college student indivual factors impact online } \\
\text { shopping behavior }\end{array}$ & No \\
\hline H7 & $\begin{array}{l}\text { perception of college student website } \\
\text { characteristics impacts perceived online } \\
\text { shopping usefulness positively. }\end{array}$ & Yes \\
\hline H8 & $\begin{array}{l}\text { perception of college student website } \\
\text { characteristics impacts college student online } \\
\text { shopping attitude positively. }\end{array}$ & Yes \\
\hline H9 & $\begin{array}{l}\text { college student perceived online shopping } \\
\text { mobility impacts perceived online shopping } \\
\text { positively. }\end{array}$ & Yes \\
\hline H10 & $\begin{array}{l}\text { college student perceived online shopping } \\
\text { usefulness impacts college student online }\end{array}$ & Yes \\
\hline
\end{tabular}




\begin{tabular}{|l|l|l|}
\hline & shopping attitude positively. & \\
\hline H11 & $\begin{array}{l}\text { college student perceived online shopping } \\
\text { usefulness impacts college student online } \\
\text { shopping intention positively. }\end{array}$ & Yes \\
\hline H12 & $\begin{array}{l}\text { college student perceived online shopping } \\
\text { mobility impacts college student online } \\
\text { shopping attitude positively. }\end{array}$ & Yes \\
\hline H13 & $\begin{array}{l}\text { college student perceived online product } \\
\text { quality information impacts online shopping } \\
\text { attitude positively. }\end{array}$ & Yes \\
\hline
\end{tabular}

\section{Conclusions}

In user groups of mobile online shopping, college students play particular and important significance. It can say that college students are core user groups in future mobile online shopping. Though consumption ability of college students is limited, they will be main force of using mobile online shopping in the future. They form a stable consumption habit of using mobile online shopping, in school time, so they will bring stable and high-quality mobile online shopping demand to mobile e-commerce enterprises, after they enter into the society. Meanwhile, for such an newly sprouted thing of mobile online shopping, college students are easier to accept it. The reason for effort expectation can become the most important influence factor is because this paper uses college students without experience as research objects. Under the premise of considering that college students have abundant usage experiment of mobile internet and traditional online shopping experience, once college students have experience, important degree of effort expectation will be reduced. College students are groups with abundant online shopping experience, so perceived risk can’t play a negative effect on initial usage intention of mobile online shopping to a higher degree.

\section{Acknowledgement}

The source of the project: the thesis for the Shaanxi Institute of International Trade \& Commerce project "mobile e-commerce adoption behavior of college students: An Empirical Study in Xi'an area as an example" of the stage research results.

\section{References}

[1] Jing Miao, the Study on Perceived Risk of Online Shopping-Based on Empirical Analysis on Shanghai College Students[M]: Shanghai: Shanghai University of Finance and Economics Press, 2006

[2] Shu Hong, Mobile E-commerce Security Issue and Countermeasures[J], Journal of Guiyang College(natural science version), 2009(4).

[3] Fan Wenjing, Consumer Behavior Analysis in Mobile Internet Era[J], Products and Quality, 2012(8): 12-58

[4] Liao Hongwei , Consumer Behavior Analysis under the Environment of Mobile Internet[J], Technological Management Research, 2013, (14): 25-69.

[5] Min Qingfei, Model Research Accepted by Chinese Mobile Business Users[J], Science and Technology of Tsinghua, 2008, (13):3-28.

[6] Stuart Barnes, Purchase Behavior in Virtual Worlds[J], An Empirical Investigation in Second Life, 2011: 305-312.

[7] Dong Dahai, Perspective Research on Perceived Risk of Consumer Online Shopping[J], Journal of Management, 2005, 2(1): 55-60

[8] Iresearch, Research Report on Behavior of Chinese Mobile Phone Users in 2011-2012[R], 2012. 
[9] He Dehua and Lu Yaobin, Research Summary on Acceptance of Mobile Business Technology[J], Journal of Univeristy of Electronic Science of Technology of China, social science version, 2008, 10(5):46-50.

[10] Sun Quan, Influence Factors on Mobile Service Usage Intention[J], Business Studies, 2009, 6: 55-59. 